The complete bibliography of Prof. RNDr. Zlatko Kvaček, DrSc. from the years 1965 - 2007 was published in Acta Musei Nationalis Pragae, Ser. B - Historia Naturalis in 2007 (Kvaček, J.: Bibliography of Prof. RNDr. Zlatko Kvaček, DrSc. - Acta Musei Nationalis Pragae, Ser. B - Historia Naturalis, 63(2-4): 75-83), and from years 2007 - 2017 in Fossil Imprint in 2018 (Sakala, J.: Bibliography of Prof. RNDr. Zlatko Kvaček, DrSc. (2007 - 2017). - Fossil Imprint, 74(1-2): 4-7).

\section{7 (addendum)}

Denk, T., Güner, T. H., Kvaček, Z., Bouchal, J. M. (2017): The early Miocene flora of Güvem (Central Anatolia, Turkey): A window into early Neogene vegetation and environments in the Eastern Mediterranean. - Acta Palaeobotanica, 57: 237-338.

\section{8}

Kvaček, Z. (2018): Cesta do pravěku - Rostlinstvo starších třetihor neboli paleogénu [Journey to the Past - Vegetation of Paleogene]. - Nová Botanika, 1(1): 5-8. (in Czech)

Kvaček, Z. (2018): Cesta do pravěku - Vodní rostlinstvo severočeského miocénu [Journey to the Past - Aquatic plants of the North Bohemian Miocene]. - Nová Botanika, 1(2): 15-16. (in Czech)

Macaluso, L., Martinetto, E., Vigna, B., Bertini, A., Cilia, A., Teodoridis, V., Kvaček, Z. (2018): Palaeofloral and stratigraphic context of a new fossil forest from the Pliocene of NW Italy. - Review of Palaeobotany and Palynology, 248: 15-33.

Winterscheid, H., Kvaček, Z., Ván̆a, J., Ignatov, M. S. (2018): Systematic-taxonomic revision of the flora from the late Oligocene Fossillagerstätte Rott near Bonn (Germany). Part 1: Introduction; Bryidae, Polypodiidae, and Pinidae. - Palaeontographica, Abteilung B: Palaeophytologie, 297: 103-141.

Kvaček, Z., Teodoridis, V., Radoň, M. (2018): Review of the late Oligocene flora of Matrý near Sebuzín (České středohoří Mts., the Czech Republic). - Fossil Imprint, 74: 292-316.

Manchester, S. R., Pigg, K. B., Kvaček, Z., Devore, M. L., Dillhoff, R. M. (2018): Newly recognized diversity in Trochodendraceae from the Eocene of Western North America. - International Journal of Plant Sciences, 179: $663-676$

\section{9}

Kvaček, Z. (2019): Cesta do pravěku - Botanická exkurze do miocenních lesů střední Evropy [Journey to the PastBotanical Excursion to the Miocene forests of Central Europe]. - Nová Botanika, 2(1): 16-19. (in Czech)
Kvaček, Z. (2019): Cesta do pravěku - Novinky ve složení evropských lesů v pliocénu [Journey to the Past - Novelties from the European Pliocene forest assemblages]. Nová Botanika, 2(2): 22-25. (in Czech)

Mantzouka, D., Sakala, J., Kvaček, Z., Koskeridou, E., Ioakim, C. (2019): Two fossil conifer species from the Neogene of Alonissos Island (Iliodroma, Greece). - Geodiversitas, 41: 125- 142.

Mantzouka, D., Sakala, J., Kvacek, Z., Koskeridou, E., Karakitsios, V. (2019): Petrified Forest of Lesbos Island (Greece): A Palaeobotanical Puzzle of a Unique Geopark and the New Discoveries. - IOP Conference Series: Earth and Environmental Science, 221: 012146 (10 pp).

Kvaček, Z., Teodoridis, V. (2019): A putative Australian element in the European Miocene re-investigated - Mahonia exulata (Unger) Kvaček \& Teodoridis comb. nov. et emend. - Neues Jahrbuch für Geologie und Paläontologie, Abhandlungen, 293: 139-143.

Kvaček, Z. (2019): Dioscorea manchesteri Kvaček, sp. nov., a new fossil species from the early Miocene flora of North Bohemia (Czech Republic). - Acta Palaeobotanica, 59: 367-371.

\section{0}

Kvaček, Z. (2020): Cesta do pravěku - Dreveník, okno do prírody konce trretihor v Evropě [Journey to the Past Dreveník, a window to the end of the European Tertiary]. - Nová Botanika, 3(1): 32-33. (in Czech)

Kvaček, Z., Teodoridis, V. (2020): A new Oligocene fern of Dryopteridaceae from the České středohoří Mts (Czech Republic). - Neues Jahrbuch für Geologie und Paläontologie, Abhandlungen, 295: 9-16.

Kvaček, Z., Teodoridis, V., Denk, T. (2020): The Pliocene flora of Frankfurt am Main, Germany: taxonomy, palaeoenvironments and biogeographic affinities. - Palaeobiodiversity and Palaeoenvironments, 100: 647-703.

Kvaček, J., Kvaček, Z. (2020): (2779) Proposal to conserve the name Aspleniopteris difformis (Comptonia difformis) against Phyllites comptoniifolius (fossil Myricaceae). Taxon, 69: 1124.

Teodoridis, V., Kvaček, Z., Radoň, M., Rapprich, V., Bruch, A. A. (2020): A new Oligocene flora from Ludvíkovice near Děčín (České středohoří Mts., the Czech Republic). - Fossil Imprint, 76(2): 297-314.

\section{in press}

Manchester, S. R., Kvaček, Z., Judd, W. S. (in press): Morphology, anatomy, phylogenetics and distribution of fossil and extant Trochodendraceae in the Northern Hemisphere. - Botanical Journal of the Linnean Society, published on-line August 9 ${ }^{\text {th }}, 2020$. https://doi.org/10.1093/botlinnean/boaa046 